\title{
DNA secondary structure is influenced by genetic variation and alters susceptibility to de novo translocation
}

Takema Kato ${ }^{1,2}$, Hidehito Inagaki ${ }^{1}$, Maoqing Tong ${ }^{1}$, Hiroshi Kogo ${ }^{1}$, Tamae Ohye ${ }^{1}$, Kouji Yamada ${ }^{1}$, Makiko Tsutsumi ${ }^{1}$, Beverly S Emanuel ${ }^{2,3}$ and Hiroki Kurahashi ${ }^{*}$

\begin{abstract}
Background: Cumulative evidence suggests that DNA secondary structures impact DNA replication, transcription and genomic rearrangements. One of the best studied examples is the recurrent constitutional $t(11 ; 22)$ in humans that is mediated by potentially cruciform-forming sequences at the breakpoints, palindromic AT-rich repeats (PATRRs). We previously demonstrated that polymorphisms of PATRR sequences affect the frequency of de novo $t$ $(11 ; 22)$ s in sperm samples from normal healthy males. These studies were designed to determine whether PATRR polymorphisms affect DNA secondary structure, thus leading to variation in translocation frequency.

Methods: We studied the potential for DNA cruciform formation for several PATRR11 polymorphic alleles using mobility shift analysis in gel electrophoresis as well as by direct visualization of the DNA by atomic force microscopy. The structural data for various alleles were compared with the frequency of de novo $t(11 ; 22)$ s the allele produced.
\end{abstract}

Results: The data indicate that the propensity for DNA cruciform structure of each polymorphic allele correlates with the frequency of de novo $t(11 ; 22)$ s produced $(r=0.77, P=0.01)$.

Conclusions: Although indirect, our results strongly suggest that the PATRR adopts unstable cruciform structures during spermatogenesis that act as translocation hotspots in humans.

Keywords: Polymorphism, Palindrome, Secondary structure, Hairpin structure, Cruciform structure, Breakpoint, Translocation

\section{Background}

Accumulating evidence indicates that alternative DNA structures (non-B DNA) cause a diversity of genomic rearrangements $[1,2]$. It is well known that a subset of repeat sequences such as trinucleotide repeats sustain dynamic mutations via DNA secondary structure intermediates leading to their expansion or contraction [3]. The finding that the $t(14 ; 18)$ translocation observed in follicular lymphoma might result from instability of triplex DNA at the breakpoint implies that gross chromosomal rearrangements can also be mediated by noncanonical DNA structures $[4,5]$. A large-scale survey

\footnotetext{
* Correspondence: kura@fujita-hu.ac.jp

'Division of Molecular Genetics, Institute for Comprehensive Medical Science, Fujita Health University, Toyoake, Aichi 470-1192, Japan Full list of author information is available at the end of the article
}

demonstrates that translocation breakpoints or deletion endpoints in human genetic diseases are consistently found in proximity to predicted non-B DNA structures [6].

Chromosomal translocations have long been thought to be random events. However, recent findings have highlighted two distinct mechanisms that lead to recurrent translocations in humans [7]. A subset of recurrent translocations arises between two homologous regions located on different chromosomes. Robertsonian translocations are mediated by highly repetitive regions on the short arms of the five acrocentric chromosomes, while $t(4 ; 8)(\mathrm{p} 16 ; \mathrm{p} 23)$ translocations result from exchange between two clusters of olfactory-receptor genes on $4 \mathrm{p}$ and $8 p$ presumably via homologous recombination $[8,9]$. Another mechanism is the so-called palindrome-
C Biomed Central 
mediated chromosomal translocation [10]. Palindromic AT-rich repeats (PATRRs) were first identified at the breakpoints of the recurrent constitutional $t(11 ; 22)$ (q23; q11) [11-13]. All of the translocation breakpoints are located within the $450 \mathrm{bp}$ PATRR on 11q23 (PATRR11) and the $590 \mathrm{bp}$ PATRR on 22q11 (PATRR22), which do not share sequence homology with one another [14]. The majority of the breakpoints are located at the center of the PATRRs, suggesting that genomic instability of the palindrome center is the etiology of the recurrent translocation [15]. PATRRs also contribute to other recurrent and non-recurrent translocations such as the $t$ $(17 ; 22)(\mathrm{q} 11 ; \mathrm{q} 11)[16,17], \mathrm{t}(4 ; 22)(\mathrm{q} 35 ; \mathrm{q} 11)$ [18], $\mathrm{t}(1 ; 22)$ (p21.2;q11) [19], and t(8;22)(q24.13;q11.21) [20,21]. Translocation-specific PCR can frequently detect de novo $\mathrm{t}(11 ; 22) \mathrm{s}$ in sperm from normal healthy males [22].

Recently, we also identified de novo PATRR-mediated $\mathrm{t}(8 ; 22) \mathrm{s}$ as well as $\mathrm{t}(8 ; 11) \mathrm{s}$ by a similar PCR method, suggesting that a considerable proportion of the translocations result from a palindrome-mediated mechanism [21].

Palindromic DNA has the potential to form a secondary structure, an extruded DNA cruciform, through the intra-strand base pairing of adjacent inverted repeat units. A number of palindromic sequences have been identified in the human genome [23], but not all of the palindromes behave as sites for translocation breakpoints. The translocation-associated PATRRs reported so far, share a common structure, 1) a nearly perfect palindrome of several hundred base pairs in length, 2) an AT-rich center and a non-AT-rich region at both ends, 3) another nearby AT-rich region on one side of the PATRR, all of which invoke cruciform structure forming propensity [24]. Indeed, the cloned PATRRs identified at the translocation breakpoints assume a cruciform conformation in vitro $[25,26]$. We propose that the PATRR also adopts a cruciform conformation in living cells, which induces genomic instability leading to translocation formation in humans. In fact, the propensity for secondary structure of the PATRRs on chromosomes 11,17 and 22 reflects the relative incidence of the relevant chromosomal translocations [27].

In our previous study, we demonstrated that the PATRR11 at the translocation breakpoint often manifests size polymorphisms due to central deletions within the PATRR11, and that this polymorphism affects the frequency of de novo $\mathrm{t}(11 ; 22) \mathrm{s}$ in sperm samples from normal healthy males [28]. Subsequently, we demonstrated that PATRR22 polymorphisms also impact de novo translocation frequency [29]. To determine whether PATRR polymorphisms influence secondary structure leading to variation in their translocation frequency, we investigated the secondary structure forming potential of each polymorphic PATRR11 and compared it with its relevant translocation frequency. The results suggest that propensity for secondary structure formation is reflected in the rate of translocations formed.

\section{Results}

\section{Size and symmetry of the palindromes affect de novo translocation frequency}

To better understand how polymorphic variants of the palindromic sequence affects de novo translocation frequency in sperm, we classified the polymorphic PATRR11s into three categories based on the size and symmetry of the palindromic sequences (Figure 1A). The most frequent allele is characterized by a nearly perfect palindromic sequence of $442-450$ bps (LPATRR11). We further grouped minor short variants into symmetric short and asymmetric short PATRR11s (SS-PATRR11 and AS-PATRR11). The size of the SSPATRR11s and AS-PATRR11s were 212-434 bp.

We attempted to estimate the frequency of de novo translocations originating from each PATRR allele. To distinguish the allelic origin of translocation products, we selected individuals heterozygous for PATRR11 polymorphisms for analysis. L-PATRR11 produces de novo translocations in approximately $10^{-5}$ gametes (1.30-2.11 $\times 10^{-5}$ ). On the other hand, variant PATRR11s generally produce translocations at a lower frequency. For SSPATRR11, the translocation frequency is about 10-fold lower than that of L-PATRR11 $\left(1.71-1.82 \times 10^{-6}\right)$, while AS-PATRR11s rarely produce de novo translocation products $(\leq 6.81 \times 10-7)$ (Table 1, Figure $1 \mathrm{~B})$. The differences in translocation frequency were statistically significant between the three groups $(P=0.01)$.

Thus, having determined that the size and symmetry of the PATRR11 appear to determine the frequency of de novo $\mathrm{t}(11 ; 22) \mathrm{s}$, it seemed reasonable to hypothesize that polymorphisms of the PATRR11 might dictate translocation frequency through their secondary structure-forming propensity.

Therefore, we analyzed the secondary structure-forming propensity of the PATRR by calculating the free energy required for a transition from standard linear double-stranded DNA to intrastrand annealing, or a socalled hairpin structure [19] (Table 1). We then analyzed the correlation between the calculated secondary structure-forming propensity of a given PATRR11 and its de novo translocation frequency. The translocation frequency did not correlate with the free energy for hairpin/cruciform formation $(r=0.37, P=0.32$ ) (Figure 1C).

In vitro analysis of cruciform extrusion of PATRR plasmids We then analyzed the in vitro cruciform-forming propensity of the PATRRs using plasmids having various PATRR11s as inserts [25,27]. First we cloned each 


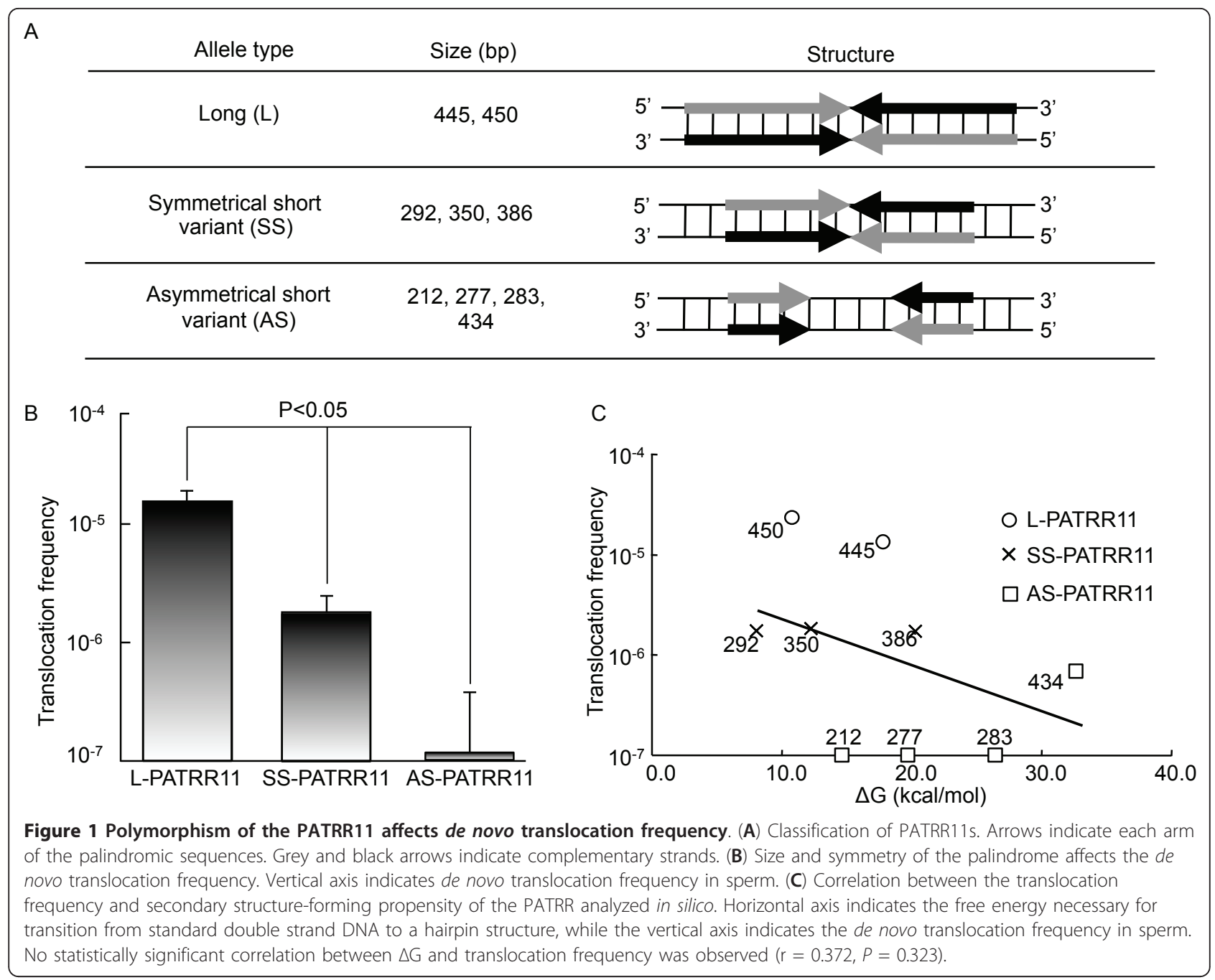

polymorphic PATRR11 into a plasmid vector and analyzed its propensity for cruciform formation by an electrophoresis mobility shift assay (EMSA). This assay is based on the fact that mobility is retarded when negative superhelical density is relieved by cruciform extrusion (Figure 2A). We extracted plasmid DNA using the triton-lysis method such that cruciform formation during DNA extraction was minimal. To induce cruciform formation, plasmids were incubated for $30 \mathrm{~min}$ at $37^{\circ} \mathrm{C}$ in $100 \mathrm{mM} \mathrm{NaCl}$. The conformation of plasmid DNA was analyzed by band shift on agarose gel electrophoresis.

Table 1 Potential secondary structure of individual PATRR11 variants by free energy calculation

\begin{tabular}{cccccc}
\hline Type of PATRR11 & Nucleotide bp (Accession No.) & $\mathbf{G}_{\mathbf{d s}}$ Kcal/mole & $\mathbf{G}_{\text {stru }}$ Kcal/mole & $\Delta \mathbf{G ~ K c a l / m o l e ~}$ & Translocation frequency \\
\hline L-PATRR11 & 445(AF391129) & -392.5 & -178.4 & 17.9 & $1.32 \times 10^{-5}$ \\
& 450(AB235178) & -397.5 & -187.9 & 10.9 & $2.11 \times 10^{-5 a}$ \\
\hline SS-PATRR11 & 292(AB235183) & -259.8 & -121.8 & 8.1 & $1.73 \times 10^{-6}$ \\
& 350(AB235180) & -314 & -144.7 & 12.3 & $1.82 \times 10^{-6 a}$ \\
& 386(AB235182) & -335.2 & -147.3 & 20.3 & $1.71 \times 10^{-6}$ \\
\hline AS-PATRR11 & 212(AF391128) & -195.6 & -83.1 & 14.7 & $<4.05 \times 10^{-8 a}$ \\
& 277(AB235187) & -247.9 & -104.2 & 19.8 & $<1.67 \times 10^{-7}$ \\
& 483(AB235186) & -252.9 & -99.95 & 26.5 & $<7.62 \times 10^{-8}$ \\
& 434(AB235190) & -380.1 & -157.3 & 32.8 & $6.81 \times 10^{-7}$ \\
\hline
\end{tabular}

\footnotetext{
${ }^{a}$ These values are the mean of 4 (450 bp L-PATRR11 allele), 2 (350 bp SS-PATRR11 allele), and 3 (212 bp AS-PATRR11 allele)samples.
} 


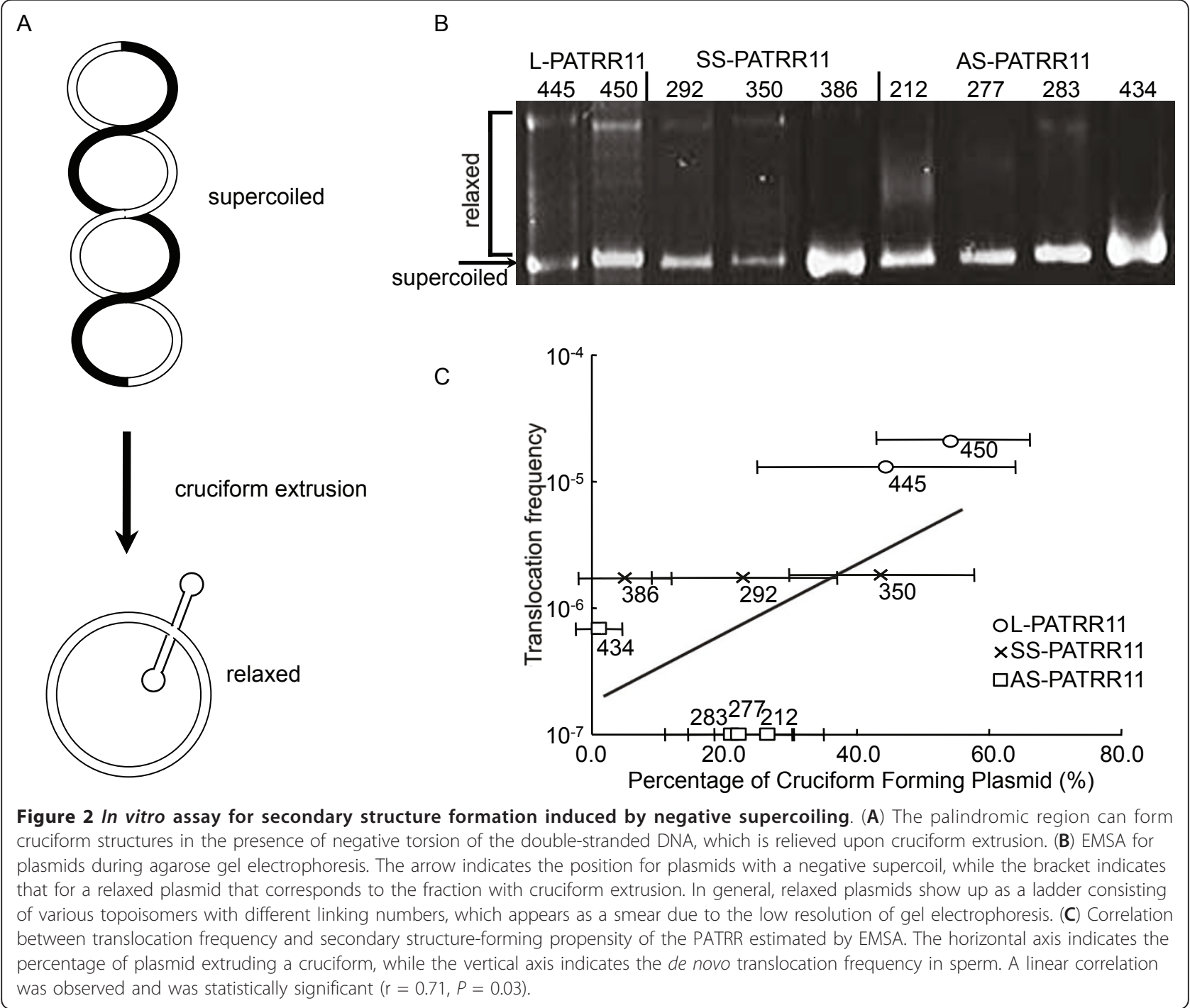

For L-PATRR11, one distinct band with retarded migration was observed accompanied by a ladder of multiple bands (Figure 2B). We confirmed that the plasmids in the retarded band extruded a cruciform by showing that the band disappeared if the plasmid was digested with T7 endonuclease prior to electrophoresis. This enzyme can cut the four-way junction of cruciform DNA (data not shown). Similar results were obtained in the analysis of SS-PATRR11, whereas AS-PATRR11 did not show such retarded bands. To estimate the percentage of cruciform forming plasmids, we summed the intensity of the retarded bands and calculated their ratio to the sum of all of the bands including the band at the standard negative supercoiled position. The ratio correlated to the frequency of de novo translocations for each allele $(\mathrm{r}=0.73, P=0.03)$ (Figure $2 \mathrm{C}$ ). However, interassay variability was significant due to difficulty in the quantification of multiple bands.
To estimate the prevalence of cruciform extrusion more accurately, EMSA was performed for the plasmid insert only. Since the PATRR cannot maintain a cruciform conformation as short linear DNA, PATRR plasmids were treated with psoralen and ultraviolet light to form covalent crosslinks prior to excision of the plasmid insert by restriction enzyme digestion. We detected a clear retarded band derived from the plasmid insert on standard agarose gel electrophoresis (Figure 3A). We confirmed that the DNAs located in the retarded bands originate from the cruciform by cleavage with $\mathrm{T} 7$ endonuclease or by direct observation using atomic force microscopy (AFM) (Figure 3B). The intensity of the retarded band on EMSA correlated well with the translocation frequency $(\mathrm{r}=0.77, P=0.01)$ (Figure $3 \mathrm{C}$ ).

\section{Discussion}

Our previous study demonstrated that the size and symmetry of polymorphic PATRRs appears to affect the 


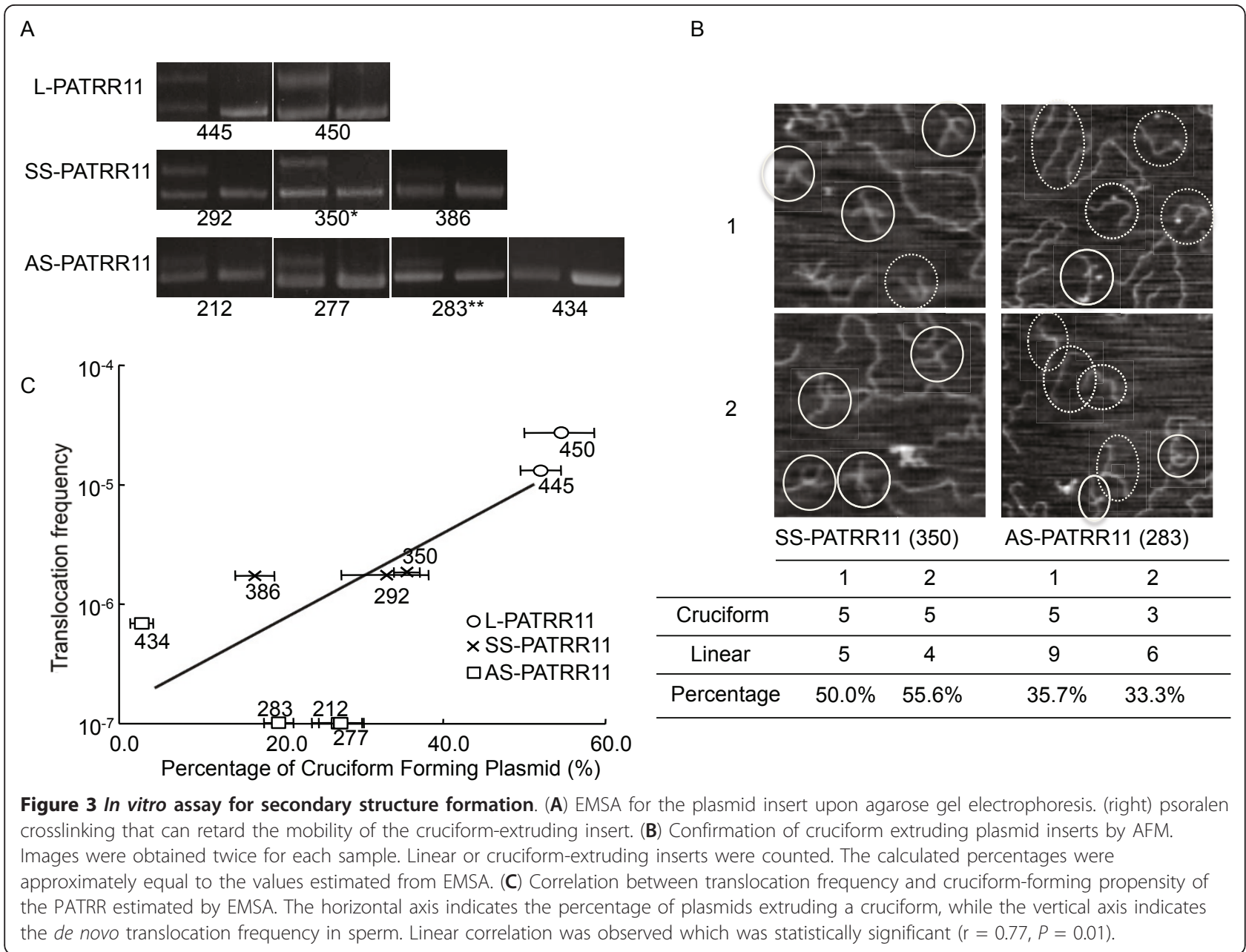

frequency of de novo $\mathrm{t}(11 ; 22) \mathrm{s}$ in sperm samples (Kato et al. 2006, Tong et al. 2010). Here we demonstrate that the size and symmetry of PATRRs reflect their secondary structure propensity. It has been suggested that polymorphic variations affect translocation frequency and induce genomic instability leading to translocation susceptibility. We recently established a model system for generating the $t(11 ; 22)$ using human somatic cell lines [30]. In this system, the endogenous PATRR11 and PATRR22 do not generate $t(11 ; 22) s$, but two co-transfected plasmids containing a PATRR11 and a PATRR22 generate translocation-like rearrangements only when transfected as cruciform-extruding plasmids. This supports the hypothesis that palindrome-mediated recurrent translocations are facilitated through cruciform extrusion of the two PATRRs.

In our data, the percentage of cruciform DNA for the L-PATRR11 was found to be high, while the translocation frequency was relatively low. One possibility is that we performed these experiments under the conditions that favored for cruciform extrusion to see the difference in cruciform propensity clearly among the PATRR11 variants. It is possible that only a small proportion of PATRRs actually extrude a cruciform in living cells. Another possibility is that the longevity of a cruciform might be transient in living cells. Cruciform extrusion requires strong free negative supercoiling, which could be easily resolved by topoisomerase activity prior to translocation formation.

Among the AS-PATRR11s, only the 434 bp PATRR11 produces translocations, although the cruciform forming propensity of the $434 \mathrm{bp}$ PATRR11 is the lowest. The 434 bp PATRR11 was the longest in length among the AS-PATRR11s we examined in this study. In our previous study, size and symmetry of the PATRR are the important determinants for translocation frequency $[28,29]$. Size might affect the stability of a cruciform once it forms, or, a cruciform-specific nuclease might more readily recognize and digest a larger cruciform leading to translocation formation.

Although a DNA cruciform is likely to be etiologic for palindrome-mediated translocations, the existence of 
DNA cruciforms in living cells is still controversial and no direct evidence has yet demonstrated the presence of such a configuration in the context of eukaryotic chromatin [31-34]. Such an energetically unfavorable structure would require sufficient negative superhelicity to stabilize the structure. However, the existence of such a level of negative supercoiling has not yet been proved. Nonetheless, the data in this study indirectly, but strongly imply that PATRRs extrude cruciform structures in living cells. Thus, the question to be answered is when and where such a structure forms and induces a translocation.

We have previously reported sperm-specific occurrence of the $t(11 ; 22)$ translocation in humans [22,35], suggesting that a physiological event during spermatogenesis might be involved in the mechanism of cruciform extrusion and/or structure-dependent instability $[36,37]$. One way to account for these observations is to postulate that translocations arise during DNA replication. Spermatogenesis engenders a greater number of replications than occur in other somatic tissues or oocytes. The majority of non-recurrent translocations are of paternal origin and de novo non-recurrent translocations are often associated with increased paternal age, despite the fact that an age-dependent increase was not observed for the occurrence of the $t(11 ; 22)$ in sperm [38-40]. One possibility is that translocations might occur late in spermatogenesis, when male-specific dynamic changes of chromatin structure take place [41].

In this study, we estimated the $\Delta G$ that reflects secondary structures formed by single-stranded DNA. These can be formed within long single-stranded regions of DNA on the lagging-strand template during DNA synthesis. Our data indicate that, similar to the PATRR22, the secondary structure forming propensity of the PATRR11 estimated by its $\Delta \mathrm{G}$ does not correlate with its translocation frequency [29]. These observations suggest that DNA replication may not significantly contribute to de novo translocation formation. This is consistent with the observation that deletions within the PATRR appear to be caused by replication errors, but translocations are not $[42,43]$. On the other hand, a significant correlate of translocation frequency is observed with the in vitro cruciform propensity of PATRR-containing plasmids under torsional constraint. During spermatogenesis standard histones are removed and replaced with protamines at a majority of chromosomal regions. The removal of histones might provide sufficient negative superhelicity to induce cruciform extrusion in vivo $[44,45]$. Such chromatin-remodelinginduced genomic instability deserves further investigation in studies designed to elucidate the mechanism and timing of gross chromosomal rearrangements.

\section{Conclusions}

In this study, a significant association between de novo translocation frequency and in vitro cruciform forming propensity of the polymorphic alleles of the PATRR11 is observed. Our results indirectly but strongly suggest that the PATRR adopts unstable cruciform structures during spermatogenesis that act as a translocation hotspot in humans.

\section{Materials and methods}

\section{PCR amplification and cloning of the PATRR}

All of the data related to PATRR11 genotype and de novo $\mathrm{t}(11 ; 22)$ translocation frequency in sperm from normal healthy males have been previously reported [28]. Samples were collected from 2 males who were heterozygous for the L- and SS-PATRR11, while 3 samples were obtained from males heterozygous for L- and AS-PATRR11. Samples from two SS/AS heterozygotes and from one AS/AS heterozygote are also included. All of the donors provided informed consent for further analysis. This study protocol was approved by the Ethical Review Board for Clinical Studies at Fujita Health University.

The PATRR11s were amplified from genomic DNA of the donors by PCR using primers described previously [28]. The plasmids containing the polymorphic PATRR11s were constructed as previously described [26] by TA cloning the PATRR11 PCR products into pT7-blue (Novagen, Madison, WI). The SURE strain (Agilent Technologies, Palo Alto, CA), whose relevant genotype concerning DNA rearrangement and deletion (recB, recJ, sbcC, umuC::Tn5, uvrC), is known to show increased stability for palindromic sequences, and was used for cloning and propagation of plasmids.

\section{In silico analysis for secondary structure}

Potential secondary structure formed within singlestranded DNA was determined by entering PATRR sequence into the $\mathrm{m}$-fold server http://mfold.rna.albany. $\mathrm{edu} / \mathrm{q} \mathrm{q}=\mathrm{mfold} / \mathrm{DNA}$-Folding-Form). A free energy value $\left(G_{\text {STRUC }}\right)$ was obtained. Similarly, free energy values for the same sequence annealed to its complementary strand $\left(G_{D S}\right)$ were obtained and then halved. Free energy for the formation of secondary structure $(\Delta G)$ is calculated as the $\mathrm{G}_{\mathrm{DS}}-\mathrm{G}_{\mathrm{STRUC}}$ difference [19].

\section{In vitro cruciform extrusion assay}

The cruciform-free plasmids were obtained by a denaturation-free, triton-lysis method as previously described [25]. In brief, the E. coli cells from a $50 \mathrm{ml}$ culture were dissolved with $10 \mathrm{ml}$ lysis buffer of $50 \mathrm{mM}$ Tris- $\mathrm{HCl}$ (pH7.5), 5\% sucrose, $1.5 \mathrm{mg} / \mathrm{ml}$ lysozyme, $0.1 \mathrm{M}$ EDTA, $25 \mu \mathrm{g} / \mathrm{ml}$ RNase A and $0.75 \%$ Triton X-100. The 
plasmids were extracted without the use of phenol, and purified using an ion-exchange column (QIAGEN, Valencia, CA). The plasmid DNA was precipitated in aliquots with 2-propanol and stored at $-30^{\circ} \mathrm{C}$ until used in an experiment. All of the procedures were performed at $4^{\circ} \mathrm{C}$ in a cold room to avoid spontaneous cruciform formation during the procedure. To induce cruciform formation, the plasmids were incubated for $30 \mathrm{~min}$ at $37^{\circ} \mathrm{C}$ in $10 \mathrm{mM}$ Tris- $\mathrm{HCl}$ (pH 7.5), $0.1 \mathrm{mM}$ EDTA and $100 \mathrm{mM} \mathrm{NaCl}$ [27]. The plasmids were cooled on ice before electrophoresis at $50 \mathrm{~V}$ for approximately 4 hours in a $0.9 \%$ agarose gel at $4{ }^{\circ} \mathrm{C}$. The gel was stained with ethidium bromide and photographed using the ImageMaster VDS system (GE Healthcare, Diegem, Belgium). Band intensities were quantified using NIH image 1.62 software.

To examine the cruciform conformation in linear DNA, DNA crosslinking was performed by a method similar to that previously described [25]. In brief, plasmid DNA was dissolved in a solution of 4, 5, 8-trimethylpsoralen $(100 \mu \mathrm{g} / \mathrm{ml})$ and exposed to UV light at $365 \mathrm{~nm}$ for 5 min. The DNA was digested with the appropriate restriction enzymes to excise the PATRR-containing fragments, purified, and then divided into two aliquots. One half was used for observation by AFM, and the other half was subjected to $2 \%$ agarose gel electrophoresis. To confirm that the shifted bands are the result of cruciform extrusion, the plasmid DNA was treated with 5 units of T7 endonuclease I (New England Biolabs, Beverly, MA). Digestion was performed in $20 \mu \mathrm{l}$ of NEB2 buffer for $40 \mathrm{~min}$. The reaction was performed on ice so as to minimize additional cruciform extrusion during digestion.

\section{Statistical analyses}

Intergroup comparison was performed by one-way analysis of variance, followed by the Mann-Whitney test. Correlations were evaluated with linear straight line regression. In significant difference tests, $P$-values of $<0.05$ were considered statistically significant.

\begin{abstract}
Acknowledgements and Funding
The authors wish to thank Dr. Anthony L. Gotter for helpful discussion and Ms. E. Hosoba and M Suzuki for technical assistances. These studies were supported by a grant-in-aid for Scientific Research from the Ministry of Education, Culture, Sports, Science and Technology of Japan, by a grant-inaid for Scientific Research from the Ministry of Health, Labour and Welfare, and by a grant from Daiko Foundation (H.K.). The studies were supported by Award Number R01CA039926 from the National Cancer Institute (BSE). The content is solely the responsibility of the authors and does not necessarily represent the official views of the National Cancer Institute or the National Institutes of Health. The studies were also supported by funds from the Charles E.H. Upham Chair (B.S.E.). One of the authors was supported by JSPS Postdoctoral Fellowships for Reseach Abroad (T.K.).
\end{abstract}

\section{Author details}

${ }^{1}$ Division of Molecular Genetics, Institute for Comprehensive Medical Science, Fujita Health University, Toyoake, Aichi 470-1192, Japan. ²Division of Human
Genetics, The Children's Hospital of Philadelphia, Philadelphia, PA 19104 USA. ${ }^{3}$ Department of Pediatrics, University of Pennsylvania School of Medicine, Philadelphia, PA 19104, USA.

\section{Authors' contributions}

TK - Participated in the design of the study, carried out the molecular biology work, and drafted the manuscript. HI - Participated in the design of the study, carried out the molecular biology work. MT - Participated in the design of the study, carried out the molecular biology work. HKO -

Participated in the design of the study, carried out the molecular biology work. TO - Participated in the design of the study, carried out the molecular biology work. KY - Participated in the design of the study, carried out the molecular biology work. MT - Participated in the design of the study, carried out the molecular biology work. BSE - Coordinated and conceived the study, being involved in the critical revision of the manuscript for important intellectual content. HKU - Coordinated and conceived the study, participated in the design of the study, drafted the manuscript, being involved in the critical revision of the manuscript for important intellectual content.

All authors have read and approved the final manuscript.

\section{Competing interests}

The authors declare that they have no competing interests.

Received: 11 June 2011 Accepted: 8 September 2011 Published: 8 September 2011

\section{References}

1. Wells RD: Non-B DNA conformations, mutagenesis and disease. Trends Biochem Sci 2007, 32:271-278.

2. Mirkin SM: Expandable DNA repeats and human disease. Nature 2007, 447:932-940.

3. Pearson CE, Nichol Edamura K, Cleary JD: Repeat instability: mechanisms of dynamic mutations. Nat Rev Genet 2005, 6:729-742.

4. Raghavan SC, Swanson PC, Wu X, Hsieh CL, Lieber MR: A non-B-DNA structure at the $\mathrm{BCl}-2$ major breakpoint region is cleaved by the RAG complex. Nature 2004, 428:88-93.

5. Raghavan SC, Chastain P, Lee JS, Hegde BG, Houston S, Langen R, Hsieh CL, Haworth IS, Lieber MR: Evidence for a triplex DNA conformation at the bcl-2 major breakpoint region of the $t(14 ; 18)$ translocation. J Biol Chem 2005, 280:22749-22760.

6. Bacolla A, Jaworski A, Larson JE, Jakupciak JP, Chuzhanova N, Abeysinghe SS, O'Connell CD, Cooper DN, Wells RD: Breakpoints of gross deletions coincide with non-B DNA conformations. Proc Natl Acad Sci USA 2004, 101:14162-14167.

7. Kurahashi $H$, Inagaki $H$, Ohye $T$, Kogo $H$, Tsutsumi $M$, Kato $T$, Tong $M$, Emanuel BS: The constitutional $t(11 ; 22)$ : implications for a novel mechanism responsible for gross chromosomal rearrangements. Clin Genet 2010, 78:299-309.

8. Shaffer $L G$, Lupski JR: Molecular mechanisms for constitutional chromosomal rearrangements in humans. Annu Rev Genet 2000, 34:297-329.

9. Giglio S, Broman KW, Matsumoto N, Calvari V, Gimelli G, Neumann T, Ohashi H, Voullaire L, Larizza D, Giorda R, et al: Olfactory receptor-gene clusters, genomic-inversion polymorphisms, and common chromosome rearrangements. Am J Hum Genet 2001, 68:874-883.

10. Kurahashi H, Bolor H, Kato T, Kogo H, Tsutsumi M, Inagaki H, Ohye T: Recent advance in our understanding of the molecular nature of chromosomal abnormalities. J Hum Genet 2009, 54:253-260.

11. Kurahashi H, Shaikh TH, Hu P, Roe BA, Emanuel BS, Budarf ML: Regions of genomic instability on $22 \mathrm{q} 11$ and $11 \mathrm{q} 23$ as the etiology for the recurrent constitutional $\mathrm{t}(11 ; 22)$. Hum Mol Genet 2000, 9:1665-1670.

12. Edelmann L, Spiteri E, Koren K, Pulijaal V, Bialer MG, Shanske A, Goldberg R, Morrow BE: AT-rich palindromes mediate the constitutional $\mathrm{t}(11 ; 22)$ translocation. Am J Hum Genet 2001, 68:1-13.

13. Tapia-Paez I, Kost-Alimova M, Hu P, Roe BA, Blennow E, Fedorova L, Imreh S, Dumanski JP: The position of $\mathrm{t}(11 ; 22)(\mathrm{q} 23 ; \mathrm{q} 11)$ constitutional translocation breakpoint is conserved among its carriers. Hum Genet 2001, 109:167-177.

14. Kurahashi H, Shaikh TH, Zackai EH, Celle L, Driscoll DA, Budarf ML, Emanuel BS: Tightly clustered 11q23 and 22q11 breakpoints permit PCR- 
based detection of the recurrent constitutional $\mathrm{t}(11 ; 22)$. Am J Hum Genet 2000, 67:763-768.

15. Kurahashi $\mathrm{H}$, Emanuel BS: Long AT-rich palindromes and the constitutional $\mathrm{t}(11 ; 22)$ breakpoint. Hum Mol Genet 2001, 10:2605-2617.

16. Kehrer-Sawatzki H, Haussler J, Krone W, Bode H, Jenne DE, Mehnert KU, Tummers $U$, Assum $G$ : The second case of a $t(17 ; 22)$ in a family with neurofibromatosis type 1: sequence analysis of the breakpoint regions. Hum Genet 1997, 99:237-247.

17. Kurahashi H, Shaikh T, Takata M, Toda T, Emanuel BS: The constitutional t (17;22): another translocation mediated by palindromic AT-rich repeats. Am J Hum Genet 2003, 72:733-738.

18. Nimmakayalu MA, Gotter AL, Shaikh TH, Emanuel BS: A novel sequencebased approach to localize translocation breakpoints identifies the molecular basis of a t(4;22). Hum Mol Genet 2003, 12:2817-2825.

19. Gotter AL, Shaikh TH, Budarf ML, Rhodes CH, Emanuel BS: A palindromemediated mechanism distinguishes translocations involving LCR-B of chromosome 22q11.2. Hum Mol Genet 2004, 13:103-115.

20. Gotter AL, Nimmakayalu MA, Jalali GR, Hacker AM, Vorstman J, Conforto Duffy D, Medne L, Emanuel BS: A palindrome-driven complex rearrangement of $22 \mathrm{q} 11.2$ and $8 \mathrm{q} 24.1$ elucidated using novel technologies. Genome Res 2007, 17:470-481.

21. Sheridan MB, Kato T, Haldeman-Englert C, Jalali GR, Milunsky JM, Zou Y, Klaes R, Gimelli G, Gimelli S, Gemmill RM, et al: A palindrome-mediated recurrent translocation with $3: 1$ meiotic nondisjunction: the $t(8 ; 22)$ (q24.13;q11.21). Am J Hum Genet 2010, 87:209-218.

22. Kurahashi H, Emanuel BS: Unexpectedly high rate of de novo constitutional $\mathrm{t}(11 ; 22)$ translocations in sperm from normal males. Nat Genet 2001, 29:139-140.

23. Tanaka H, Bergstrom DA, Yao MC, Tapscott SJ: Widespread and nonrandom distribution of DNA palindromes in cancer cells provides a structural platform for subsequent gene amplification. Nat Genet 2005, 37:320-327.

24. Kurahashi H, Inagaki H, Hosoba E, Kato T, Ohye T, Kogo H, Emanuel BS: Molecular cloning of a translocation breakpoint hotspot in $22 q 11$. Genome Res 2007, 17:461-469.

25. Kurahashi $H$, Inagaki H, Yamada K, Ohye T, Taniguchi M, Emanuel BS, Toda T: Cruciform DNA structure underlies the etiology for palindromemediated human chromosomal translocations. J Biol Chem 2004, 279:35377-35383.

26. Inagaki H, Ohye T, Kogo H, Yamada K, Kowa H, Shaikh TH, Emanuel BS, Kurahashi $\mathrm{H}$ : Palindromic AT-rich repeat in the NF1 gene is hypervariable in humans and evolutionarily conserved in primates. Hum Mutat 2005, 26:332-342.

27. Kogo H, Inagaki H, Ohye T, Kato T, Emanuel BS, Kurahashi H: Cruciform extrusion propensity of human translocation-mediating palindromic ATrich repeats. Nucleic Acids Res 2007, 35:1198-1208.

28. Kato T, Inagaki H, Yamada K, Kogo H, Ohye T, Kowa H, Nagaoka K, Taniguchi M, Emanuel BS, Kurahashi H: Genetic variation affects de novo translocation frequency. Science 2006, 311:971.

29. Tong M, Kato T, Yamada K, Inagaki H, Kogo H, Ohye T, Tsutsumi M, Wang J, Emanuel BS, Kurahashi H: Polymorphisms of the 22q11.2 breakpoint region influence the frequency of de novo constitutional $t(11 ; 22) \mathrm{s}$ in sperm. Hum Mol Genet 2010, 19:2630-2637.

30. Inagaki $H$, Ohye $T$, Kogo $H$, Kato $T$, Bolor $H$, Taniquchi M, Shaikh TH, Emanuel BS, Kurahashi H: Chromosomal instability mediated by non-B DNA: cruciform conformation and not DNA sequence is responsible for recurrent translocation in humans. Genome Res 2009, 19:191-198.

31. Lobachev KS, Gordenin DA, Resnick MA: The Mre11 complex is required for repair of hairpin-capped double-strand breaks and prevention of chromosome rearrangements. Cell 2002, 108:183-193.

32. Lemoine FJ, Degtyareva NP, Lobachev K, Petes TD: Chromosomal translocations in yeast induced by low levels of DNA polymerase a model for chromosome fragile sites. Cell 2005, 120:587-598.

33. Zhang $\mathrm{H}$, Freudenreich $\mathrm{CH}$ : An AT-rich sequence in human common fragile site FRA16D causes fork stalling and chromosome breakage in S. cerevisiae. Mol Cell 2007, 27:367-379.

34. Cote AG, Lewis SM: Mus81-dependent double-strand DNA breaks at in vivo-generated cruciform structures in S. cerevisiae. Mol Cell 2008, 31:800-812.
35. Ohye T, Inagaki $H$, Kogo H, Tsutsumi M, Kato T, Tong M, Macville MV, Medne L, Zackai EH, Emanuel BS, Kurahashi H: Paternal origin of the de novo constitutional $\mathrm{t}(11 ; 22)(\mathrm{q} 23 ; \mathrm{q} 11)$. Eur J Hum Genet 2010, 18:783-787.

36. Kurahashi $H$, Inagaki H, Ohye T, Kogo H, Kato T, Emanuel BS: Chromosomal translocations mediated by palindromic DNA. Cell Cycle 2006, 5:1297-1303

37. Kurahashi H, Inagaki H, Ohye T, Kogo H, Kato T, Emanuel BS: Palindromemediated chromosomal translocations in humans. DNA Repair (Amst) 2006, 5:1136-1145.

38. Thomas NS, Morris JK, Baptista J, Ng BL, Crolla JA, Jacobs PA: De novo apparently balanced translocations in man are predominantly paternal in origin and associated with a significant increase in paternal age. $J$ Med Genet 2010, 47:112-115.

39. Templado C, Donate A, Giraldo J, Bosch M, Estop A: Advanced age increases chromosome structural abnormalities in human spermatozoa. Eur J Hum Genet 2011, 19:145-151.

40. Kato T, Yamada K, Inagaki H, Kogo H, Ohye T, Emanuel BS, Kurahashi H: Age has no effect on de novo constitutional t(11;22) translocation frequency in sperm. Fertil Steril 2007, 88:1446-1448.

41. Ward WS: Function of sperm chromatin structural elements in fertilization and development. Mol Hum Reprod 2010, 16:30-36.

42. Kato T, Inagaki H, Kogo H, Ohye T, Yamada K, Emanuel BS, Kurahashi H: Two different forms of palindrome resolution in the human genome: deletion or translocation. Hum Mol Genet 2008, 17:1184-1191.

43. Kurahashi $H$, Inagaki $H$, Kato $T$, Hosoba E, Kogo H, Ohye T, Tsutsumi M, Bolor $\mathrm{H}$, Tong M, Emanuel BS: Impaired DNA replication prompts deletions within palindromic sequences, but does not induce translocations in human cells. Hum Mol Genet 2009, 18:3397-3406.

44. Kovtun IV, McMurray CT: Trinucleotide expansion in haploid germ cells by gap repair. Nat Genet 2001, 27:407-411.

45. Laberge RM, Boissonneault G: Chromatin remodeling in spermatids: a sensitive step for the genetic integrity of the male gamete. Arch Androl 2005, 51:125-133.

doi:10.1186/1755-8166-4-18

Cite this article as: Kato et al:: DNA secondary structure is influenced by genetic variation and alters susceptibility to de novo translocation. Molecular Cytogenetics 2011 4:18.

\section{Submit your next manuscript to BioMed Central and take full advantage of:}

- Convenient online submission

- Thorough peer review

- No space constraints or color figure charges

- Immediate publication on acceptance

- Inclusion in PubMed, CAS, Scopus and Google Scholar

- Research which is freely available for redistribution

Submit your manuscript at www.biomedcentral.com/submit
Ciomed Central 